\title{
Oil-in-water emulsions characterization by laser granulometry and impact on $\gamma$-decalactone production in Yarrowia lipolytica
}

\author{
Nelma Gomes · Yves Waché • José A. Teixeira • \\ Isabel Belo
}

Received: 21 January 2011/Accepted: 10 March 2011/Published online: 24 March 2011

(C) Springer Science+Business Media B.V. 2011

\begin{abstract}
Oil-in-water emulsions composed of methyl ricinoleate (MR) or castor oil (CO) as the organic phase, stabilized by Tween 80 , are in the basis of the biotechnological production of $\gamma$-decalactone. Yarrowia lipolytica was used due to its ability to grow on hydrophobic substrates and to carry out the biotransformation. The characterization of oil droplets size distribution by laser granulometry was performed under different oil concentrations. The impact of the presence of cells on droplets size was also analyzed as well as the relevance of washing inoculum cells. Furthermore, the granulometric characterization of the emulsions was related with $\gamma$-decalactone production and it was observed that, in the presence of non-washed cells, the smaller droplets disappeared, using both oils, which increased $\gamma$-decalactone concentration. This
\end{abstract}

N. Gomes · J. A. Teixeira · I. Belo $(\bowtie)$

IBB-Institute for Biotechnology and Bioengineering, Center of Biological Engineering, University of Minho, Campus de Gualtar, 4710-057 Braga, Portugal e-mail: ibelo@deb.uminho.pt

N. Gomes

e-mail: nelmagomes@deb.uminho.pt

J. A. Teixeira

e-mail: jateixeira@deb.uminho.pt

Y. Waché

Laboratoire GPMA, Université de Bourgogne/AgroSup

Dijon, 1, esplanade Erasme, 21000 Dijon, France

e-mail: Yves.Wache@u-bourgogne.fr suggests that the access of cells to the substrate occurs by their adhesion around larger oil droplets.

Keywords Castor oil $\cdot \gamma$-Decalactone $\cdot$ Droplet size distribution - Emulsions - Methyl ricinoleate

\section{Introduction}

The biotechnological production of $\gamma$-decalactone, a fruity-like aroma compound, results from the biotransformation of ricinoleic acid and it can be carried out by several microorganisms, among which the dimorphic yeast Yarrowia lipolytica (Aguedo et al. 2005a).

The medium usually used is composed by an oilin-water emulsion stabilized by a non-ionic surfactant, Tween 80 . The oil is the source of ricinoleic acid, usually methyl ricinoleate (MR) or castor oil (CO).

The growth of cells in a medium containing lipids occurs directly on droplets as their solubility in water is limited (Gutierrez and Erickson 1977) and it is, thus, influenced by the size of the oil droplets (Bakhuis and Bos 1969).

The interfacial surface of the oil droplets and consequently the surface between the two liquid phases is a determining factor for the degradation of the hydrophobic substrate and, thus, for the cells, growth and aroma production (Aguedo et al. 2005b). 
The lipidic droplets size is influenced by numerous parameters which may be related to physical and chemical characteristics of the medium $(\mathrm{pH}$, ionic strength, presence of surfactants, etc.) (Wilde 2000) or to the presence of microorganisms (inoculum concentration, cells surface properties, etc.). During the biotransformation of ricinoleic acid into $\gamma$ decalactone, there is a direct contact between the cells surface and the substrate droplets which may occur by adhesion of cells to the larger droplets surface or by adsorption of micro-droplets at the cells surface (Bakhuis and Bos 1969).

Since the access of the cells to the substrate depends on the emulsion characteristics, emulsions were characterized by determining the oil droplets size distribution, through the laser granulometry technique, using both oils (MR and CO), at different concentrations and in the presence or absence of cells. Moreover, since the cells surface properties may influence the interaction between the oil and cells, different methodologies were used for inoculum cells preparation, according with Gomes et al. (2010). This procedure had an impact on cells hydrophobic character and the effect on emulsion behaviour was analyzed in the present work. In a last instance, the impact of each emulsion on $\gamma$-decalactone production was also investigated.

\section{Materials and methods}

Microorganism, media and culture conditions

Yarrowia lipolytica W29 (ATCC20460) was cultured for $48 \mathrm{~h}$ on YPDA medium ( $30 \mathrm{~g}$ agar $\mathrm{l}^{-1}, 20 \mathrm{~g}$ glucose $1^{-1}, 20 \mathrm{~g}$ peptone $1^{-1}, 10 \mathrm{~g}$ yeast extract $\mathrm{l}^{-1}$ ) at $27^{\circ} \mathrm{C}$ and used to inoculate (to reach $\mathrm{OD}_{600}$ of $\sim 0.25$ ) a $500 \mathrm{ml}$ baffled Erlenmeyer flask containing $200 \mathrm{ml}$ glucose medium (YPD medium: glucose $20 \mathrm{~g}$ glucose $1^{-1}, 20 \mathrm{~g}$ peptone $1^{-1}, 10 \mathrm{~g}$ yeast extract $\mathrm{l}^{-1}$ ). Flasks were shaken at $140 \mathrm{rpm}$ and $27^{\circ} \mathrm{C}$ for $19 \mathrm{~h}$ until the cultures reached the late growth phase. This suspension was used to inoculate the biotransformation medium.

Two sources of ricinoleic acid were used: MR and $\mathrm{CO}$ at different concentrations. The composition of the biotransformation medium was: $6.7 \mathrm{~g}$ YNB (yeast nitrogen base) with amino acids $1^{-1}, 2.5 \mathrm{~g} \mathrm{NH}_{4} \mathrm{Cl}^{-1}$, from 10 to $50 \mathrm{~g} \mathrm{MR}$ or $\mathrm{CO}^{-1}$ and from 1 to $5 \mathrm{~g}$
Tween $801^{-1}$. Two methodologies were tested for inoculation of the biotransformation medium: with or without the cell washing step. In the first case, cells from the YPD medium were washed three times in sterile water, centrifuged $(6000 \times g, 5 \mathrm{~min})$ and transferred to the biotransformation medium. In the second, the components of the biotransformation medium were directly added to the YPD medium containing the cells (Gomes et al. 2010).

All chemicals were purchased from Sigma-Aldrich except for CO, which was purchased from José M. Vaz Pereira (Sintra, Portugal) and MR, which was kindly supplied by Stéarinerie Dubois (Boulogne, France).

$\gamma$-Decalactone extraction and quantification

$\gamma$-Decalactone was extracted from $2 \mathrm{ml}$ broth with $2 \mathrm{ml}$ diethyl ether. The organic phase was analyzed by GC as described in previous work (Gomes et al. 2010).

\section{Laser granulometry}

The droplet size distribution of MR and CO emulsions was evaluated using a Malvern Mastersizer laser granulometer (Model S2-01, Malvern Instruments, Malvern, UK), based on the Fraunhofer approximation (Agrawal et al. 1991).

Emulsions with MR and CO were analyzed with and without cells precultured during $19 \mathrm{~h}$ on YPD medium. For the essays without cells, the emulsions were shaken during $1.25 \mathrm{~h}$ prior to analysis. For the experiments with cells, the emulsions were shaken for $1 \mathrm{~h}$ before inoculation and then for more $15 \mathrm{~min}$, with cells, before analysis. A cellular suspension prepared in sterile water was also analyzed, in order to determine the size of the yeast cells. All assays were performed in triplicate.

\section{Results and discussion}

The granulometric analyses of the emulsified MR and CO media, without cells, indicated the existence of two distinct droplet populations (Fig. 1). In the population with smaller dimension, the droplets size remained practically with the same mean value among all MR $(1.5 \mu \mathrm{m})$ and $\mathrm{CO}(1.9 \mu \mathrm{m})$ concentrations tested. In the 

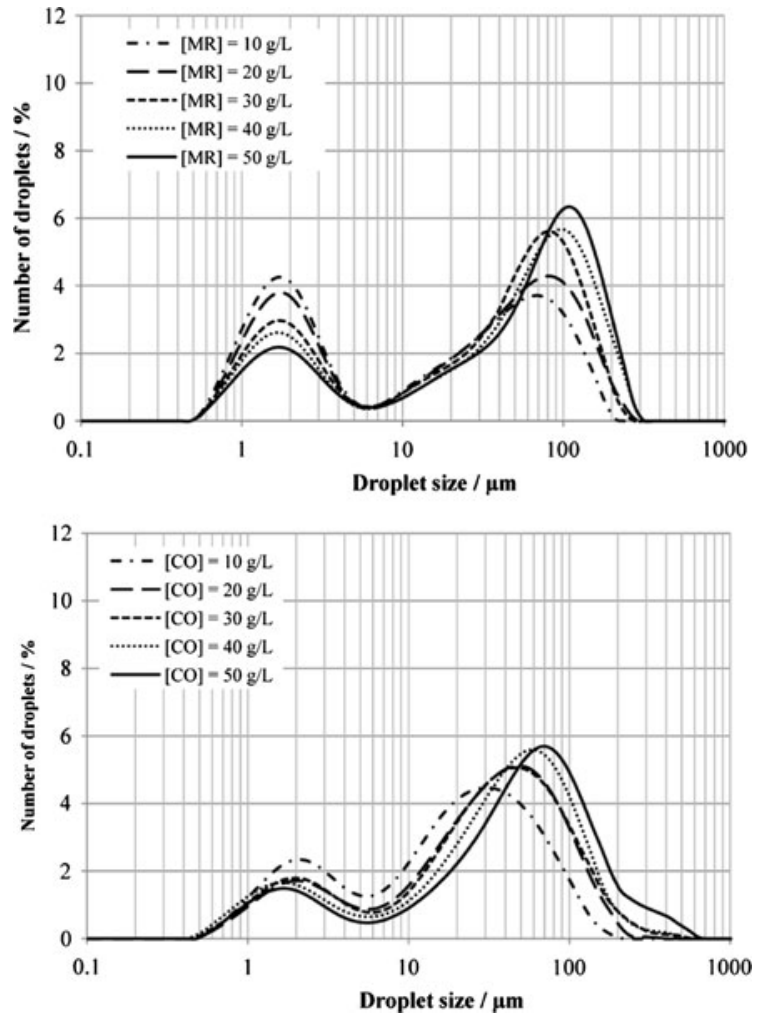

Fig. 1 Methyl ricinoleate (MR) and castor oil (CO) droplets size distribution (in $\mu \mathrm{m}$ ) in emulsions without cells, related to the number of particles (in \%). Data are the mean of three independent experiments

larger size population, the mean droplets diameter increased from 61 to $96 \mu \mathrm{m}$, with the increase in MR concentration, and from 27 to $64 \mu \mathrm{m}$, with the increase in $\mathrm{CO}$ concentration. Moreover, there was an increase in percentage of larger droplets with the oil concentration increase.

Aguedo et al. (2003) have also characterized an emulsion composed by $10 \mathrm{~g} \mathrm{MR} \mathrm{l}^{-1}$. The results obtained by these authors differ from those presented in this work since they have reported the existence of three distinct droplet populations with mean sizes of $0.1,3$ and $43 \mu \mathrm{m}$, in the MR emulsion. These divergences may be justified by a variation in the concentration of Tween $80\left(0.2 \mathrm{~g} \mathrm{l}^{-1}\right.$ vs. $1 \mathrm{~g} \mathrm{l}^{-1}$, in their work and in the present one, respectively). Thus, it seems that the use of a higher concentration of surfactant has an impact upon the MR droplets size, since the smaller droplets $(0.1 \mu \mathrm{m})$ disappeared and a population of larger droplets emerged: $61 \mu \mathrm{m}$ in this study, compared with $43 \mu \mathrm{m}$ in their work.

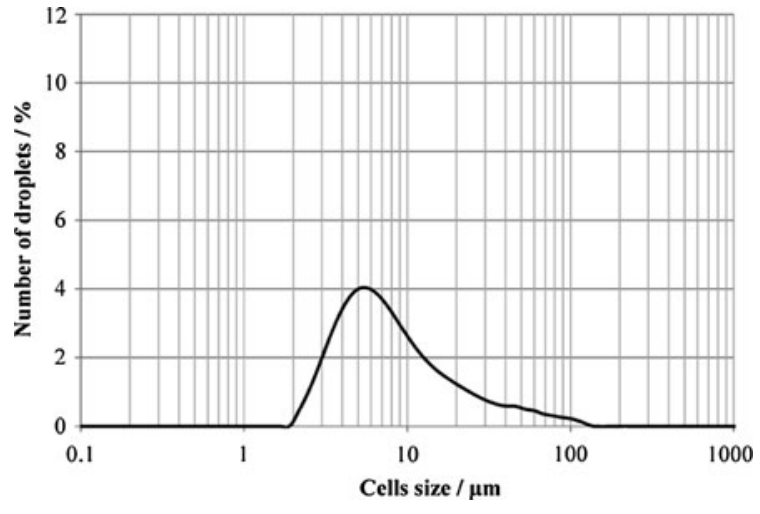

Fig. 2 Cells size distribution (in $\mu \mathrm{m}$ ) in sterile water, related to the number of particles (in \%). Data are the mean of three independent experiments

Prior to the determination of droplets size in the presence of cells, the cells size distribution was evaluated by suspending the cells in sterile water. A population with mean values of $5.4 \mu \mathrm{m}$ was detected, corresponding to an oval morphology (Lopes et al. 2007) (Fig. 2).

When cells were present at around $1.5 \times 10^{9} \mathrm{ml}^{-1}$ in the MR and CO emulsions, there were still two populations (in some cases, three) with different particle sizes (Figs. 3, 4). However, drops with $1.5-1.9 \mu \mathrm{m}$ size disappeared in all emulsions. This disappearance, due to the presence of cells, may be explained by the adhesion of smaller substrate droplets to the cells surface and to the higher number of cell particles that would overshadow the smallest oil droplets (Aguedo et al. 2003). Nevertheless, the population of cells remained with a mean size of approximately $5.4 \mu \mathrm{m}$. The existence of this population was also reported by Aguedo et al. (2003).

When washed cells were used (Fig. 3), a population had a mean oil droplet size of $0.9 \mu \mathrm{m}$, although in a small percentage number, in all experiments and for both oils. This decrease in the oil droplets mean size with the addition of Y. lipolytica washed cells was also stated by Waché et al. (2000), when using emulsions composed by $5 \mathrm{~g} \mathrm{MR}^{-1}$ and $1 \mathrm{~g}$ Tween $80 \mathrm{l}^{-1}$.

Another population, with a mean droplet size comprised between 32 and $40 \mu \mathrm{m}$, was also noticed in all experiments and for both substrates, although with a larger number of particles in $\mathrm{CO}$ emulsions. Aguedo et al. (2003) also described the existence of a population of MR droplets with a mean size of $42 \mu \mathrm{m}$, in emulsions with $Y$. lipolytica washed cells. 

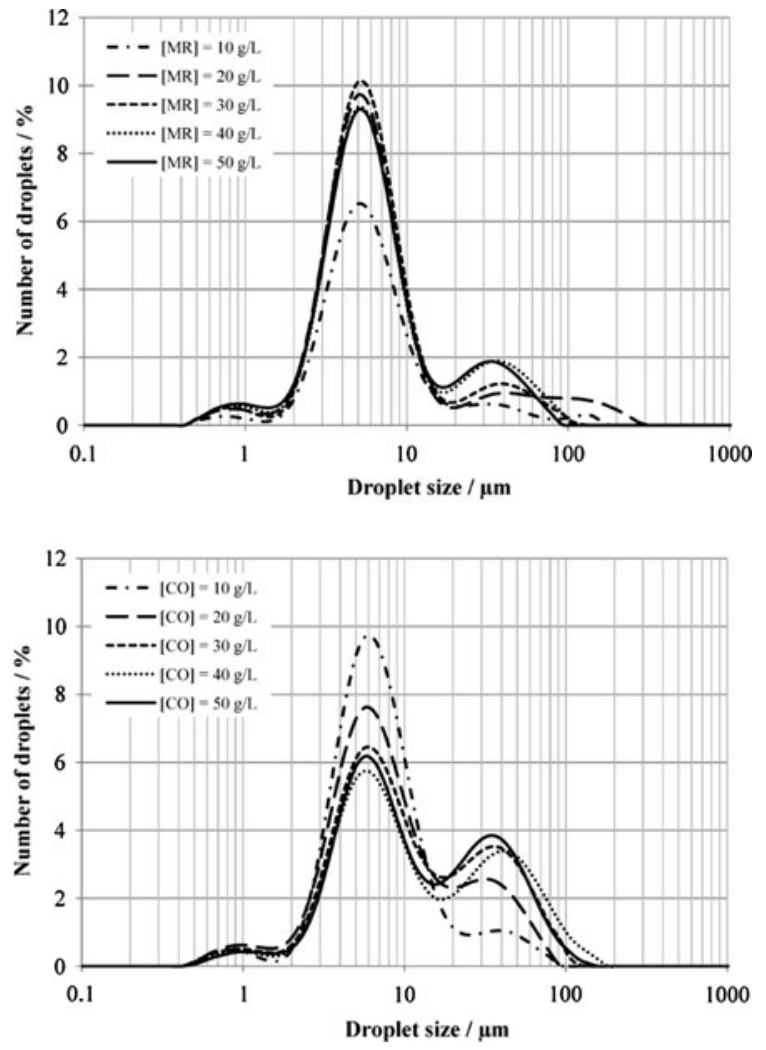

Fig. 3 Methyl ricinoleate (MR) and castor oil (CO) droplets size distribution (in $\mu \mathrm{m}$ ) in emulsions with washed cells, related to the number of particles (in \%). Data are the mean of three independent experiments

In the experiments involving non-washed cells (Fig. 4), as the concentration of MR increased, the size of oil droplets also increased slightly, ranging from 40 to $69 \mu \mathrm{m}$, except for the experiment with $50 \mathrm{~g}$ MR $1^{-1}$, which presented a mean size of $52 \mu \mathrm{m}$.

When comparing the experiments with washed and non-washed cells, using both oils, one can observe that the smallest oil droplets disappeared (except for the case with $50 \mathrm{~g} \mathrm{CO}^{-1}$, where the existence of a small population of oil droplets with a mean size of $0.8 \mu \mathrm{m}$ was noticed). This disappearance is probably related to the higher hydrophobicity of non-washed cells, as proved in previous work (Gomes et al. 2010), allowing droplets to adsorb to their surface, turning its presence not measurable.

Table 1 shows that the accumulation of $\gamma$-decalactone is directly dependent on the MR concentration, with the greater production of aroma occurring when the substrate concentration is higher. The
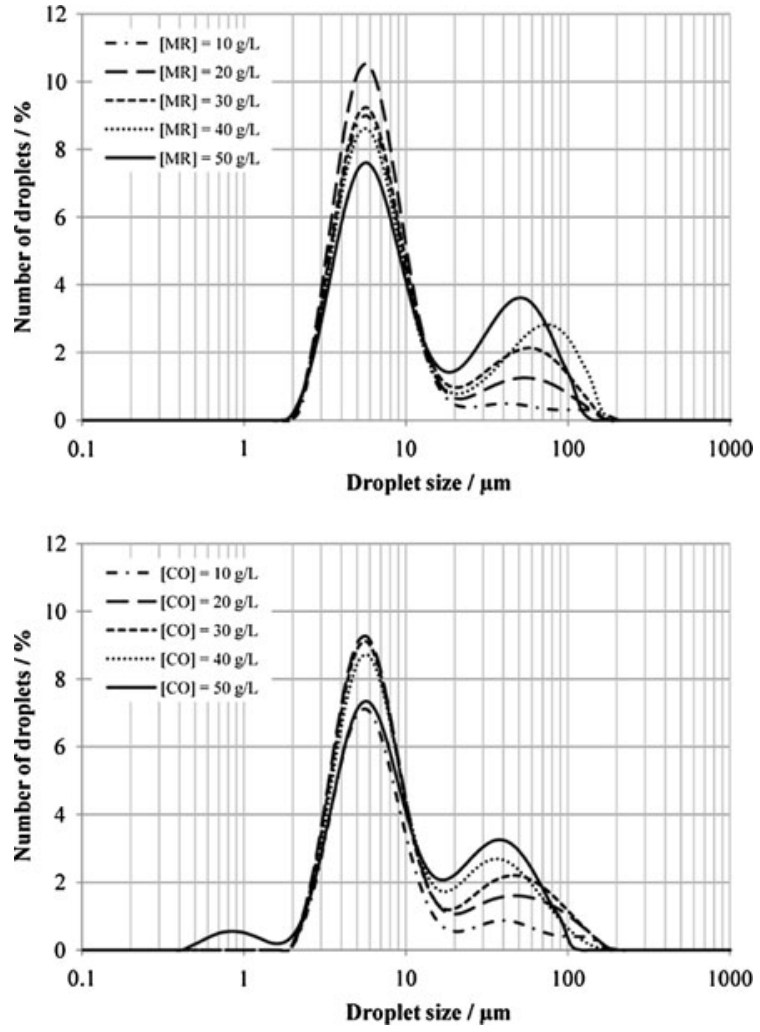

Fig. 4 Methyl ricinoleate (MR) and castor oil (CO) droplets size distribution (in $\mu \mathrm{m}$ ) in emulsions with non-washed cells, related to the number of particles (in \%). Data are the mean of three independent experiments

accumulation of $\gamma$-decalactone was also greater when non-washed cells are used. In this situation, the MR droplets size is higher (the smaller population with $0.9 \mu \mathrm{m}$ disappeared), suggesting that higher particle sizes are more favorable to the production of the aroma, indicating that the adhesion of cells to the substrate occurs by the linkage of cells around larger oil droplets (Bakhuis and Bos 1969). In fact, cells possess a much smaller size than the oil droplets and the number of cell particles is far superior to the number of oil particles, which seems to corroborate the hypothesis proposed.

With respect to the use of $\mathrm{CO}$ and non-washed cells, the size of oil droplets varied from 34 to $46 \mu \mathrm{m}$, for the larger population (Fig. 4).

When castor oil is used as substrate of the process, there is no aroma production when washed cells are used in the biotransformation. When using nonwashed cells, the most adequate oil concentration to be employed, in terms of overall productivity, is 
Table 1 Mean droplet size (highest), maximum $\gamma$-decalactone accumulation and yield in respect to the substrate $\left(Y_{P / S}\right)$ achieved in biotransformation media with different MR or CO concentrations and with washed or non-washed cells

\begin{tabular}{|c|c|c|c|c|c|c|c|}
\hline & \multirow[t]{2}{*}{ Oil $\left(\mathrm{g} \mathrm{l}^{-1}\right)$} & \multicolumn{3}{|l|}{ Washed cells } & \multicolumn{3}{|c|}{ Non-washed cells } \\
\hline & & $\begin{array}{l}\text { Maximum mean } \\
\text { droplet size }(\mu \mathrm{m})\end{array}$ & $\begin{array}{l}\gamma \text {-Decalactone } \\
\left(\mathrm{mg} \mathrm{l}^{-1}\right)\end{array}$ & $\begin{array}{l}\mathrm{Y}_{\mathrm{P} / \mathrm{S}} \\
\left(\mathrm{mg} \mathrm{g}^{-1}\right)\end{array}$ & $\begin{array}{l}\text { Mean droplet } \\
\text { size }(\mu \mathrm{m})\end{array}$ & $\begin{array}{l}\gamma \text {-Decalactone } \\
\left(\mathrm{mg} \mathrm{l}^{-1}\right)\end{array}$ & $\begin{array}{l}\mathrm{Y}_{\mathrm{P} / \mathrm{S}} \\
\left(\mathrm{mg} \mathrm{g}^{-1}\right)\end{array}$ \\
\hline \multirow[t]{3}{*}{ MR } & 10 & 32.4 & 173 & 17.3 & $5.4 ; 39.8$ & 434 & 43.4 \\
\hline & 30 & 39.8 & 284 & 9.5 & $5.4 ; 60.2$ & 724 & 24.1 \\
\hline & 50 & 34.7 & 471 & 9.4 & $5.4 ; 52.5$ & 997 & 19.9 \\
\hline \multirow[t]{3}{*}{$\mathrm{CO}$} & 10 & 39.8 & 0 & 0 & $5.4 ; 39.8$ & 1371 & 137.1 \\
\hline & 30 & 34.7 & 0 & 0 & $5.4 ; 45.7$ & 1839 & 61.3 \\
\hline & 50 & 34.7 & 0 & 0 & $5.4 ; 39.8$ & 1339 & 26.8 \\
\hline
\end{tabular}

$30 \mathrm{~g}^{-1}$, suggesting that the most favorable droplets size corresponds to a diameter of approx. $46 \mu \mathrm{m}$, the larger size determined among all $\mathrm{CO}$ emulsions. This corroborates the hypothesis previously suggested about larger particle sizes being more favorable to the aroma production.

The main differences obtained in the aroma production under different operating conditions cannot be attributed solely to the size of oil droplets; the quantity of available substrate for cells to use in the biotransformation, as well as to the cells surface properties, which determines how the substrate is assimilated, need to be taken into account. Gomes et al. (2010) verified, by means of the MATH test, that there was a greater adhesion of non-washed cells to hexadecane, than of washed cells. These differences point out that non-washed cells are more compatible with the substrate, which might also explain the divergences obtained in the production of $\gamma$-decalactone, apart from the differences in the oil droplets size.

\section{Conclusion}

This study aimed to characterize the oil droplets size distribution on different oil-in-water emulsions, composed by different concentrations of methyl ricinoleate or castor oil and stabilized by a non-ionic surfactant. The impact of the presence of cells on droplets size was shown, as well as the relevance of a washing step of the inoculum cells.

In the experiments without cells, an increase in both oil concentrations leaded to an enlargement of the mean oil droplets size. In the presence of cells, there are two or three populations with different particle sizes. However, when cells were washed, a smaller population of both oil droplets was detected.

Moreover, the granulometric characterization of the emulsions was related with $\gamma$-decalactone accumulation profiles and allowed to conclude that larger oil droplets favors the aroma production, suggesting that, in this case, the access of cells to the substrate occurs by their adhesion around larger oil droplets.

The obtained results are an important contribution for a better understanding of the factors affecting the assimilation of hydrophobic compounds by Y. lipolytica, clearly demonstrating the impact of substrate concentration, as well as of cells, on droplet size distribution and, consequently, on $\gamma$-decalactone production.

Acknowledgments The authors acknowledge Fundação para a Ciência e Tecnologia (FCT) for the financial support provided (SFRH/BD/28039/2006) and CRUP (Cooperation project F-41/06).

\section{References}

Agrawal YC, McCave IN, Riley JB (1991) Laser diffraction size analysis. In: Syvitski JPM (ed) Principles methods and application of particle size analysis. Cambridge University Press, New York, pp 119-128

Aguedo M, Waché Y, Mazoyer V, Le Grand AS, Belin J-M (2003) Increased electron donor and electron acceptor characters enhance the adhesion between oil droplets and cells of Yarrowia lipolytica as evaluated by a new cytometric assay. J Agric Food Chem 51:3007-3011

Aguedo M, Gomes N, Teixeira JA, Belo I (2005a) Decalactone production by Yarrowia lipolytica under increase $\mathrm{O}_{2}$ transfer rates. Biotechnol Lett 27:1617-1621

Aguedo M, Waché Y, Belin J-M, Teixeira JA (2005b) Surface properties of Yarrowia lipolytica and their relevance to $\gamma$-decalactone formation from methyl ricinoleate. Biotechnol Lett 27:417-422 
Bakhuis E, Bos P (1969) Correlation between growth of Candida lipolytica and size of droplets in the hydrocarbon containing medium. Antonie van Leeuwenhoek 35:F47F48

Gomes N, Teixeira JA, Belo I (2010) The use of methyl ricinoleate in lactone production by Yarrowia lipolytica: aspects of bioprocess operation that influence the overall performance. Biocatal Biotransform 28(4):227-234

Gutierrez JR, Erickson LE (1977) Hydrocarbon uptake in hydrocarbon fermentations. Biotechnol Bioeng 19(9): 1331-1349
Lopes M, Gomes N, Gonçalves C, Coelho MAZ, Mota M, Belo I (2007) Yarrowia lipolytica lipase production enhanced by increased air pressure. Lett Appl Microbiol 46: 255-260

Waché Y, Bergmark K, Courthaudon J-L, Aguedo M, Nicaud J-M, Belin J-M (2000) Medium-size droplets of methyl ricinoleate are reduced by cell-surface activity in the $\gamma$-decalactone production by Yarrowia lipolytica. Lett Appl Microbiol 30:183-187

Wilde PJ (2000) Interfaces: their role in foam and emulsion behavior. Curr Opin Colloid Interface Sci 5:176-181 